\title{
PAPEL DA MÁ LITERATURA DOS "COMICS"(*) NORTE-AMERICANOS SOBBRE O PSIQUISMO DAS CRIANÇAS E DOS ADOLESCENTES
}

Comunicação apresentada ao $5 .^{\circ}$ Congresso Internacional de Psiquiatria Infantil, realizado em Scheveningen (Holanda), no mês de agôsto de 1962, pelo

\section{Prof. Dr. Napoleão L. Teixeira}

Professor de Medicina Legal (Faculdade de Direiţo) e de Clínica Psiquiátrica (Faculdade de Medicina), da Universidade do Paraná.

Entre os fatôres que, no Brasil, representam um papel importante na distorção do psiquismo da criança e do adolescente, assinale-se - de par com o mau cinema, o mau teatro, o mau rádio, a má televisão, os maus livros, o jornalismo sensacionalista, etc. - a influência altamente nociva da má literatura infantil, fornecida pelos "comics" norte-americanos, que poderosos "Syndicates" jornalísticos nos impõem, envenenando o espírito das crianças e adolescentes de nosso País.

Fartamente disseminada no Brasil, reproduzida e imitada por numerosas revistas e grande número dos maiores jornais brasileiros, essa literatura - exceções, raras, à parte - nada tem de boa, sendo, antes, má, deletéria e mesmo perigosa.

Temos, em síntese, de um lado, a criança, instável, impulsiva, egoísta, imaginativa, sugestionável - ser de imitação e não de raciocínio - e, de outro lado, temos os "comics", agindo de maneira fortemente perniciosa, perseverante, tenaz, sôbre o seu psiquismo, através do mais vulnerável dos órgãos dos sentidos: a visão.

No ano de 1948, sòmente nos Estados Unidos, essas publicações eram feitas à razão de 60 milhões por mês, isto é, 720 milhões

(*) "Histórias-em-quadrinhos" (Brasil); "comics" (Estados Unidos); "bandes dessinées" (França); "fumetti" (Itália), etc. 
anuais; em outras palavras, mais que a circulação, total de dez dos maiores jornais reunidos. Atualmente, a cifra de 100 milhões mensais já foi ultrapassada.

Relata o "Chicago Tribune" que, nesse país, 25 a 30 milhões de pessoas lêm o "comic" "Dick Tracy", um dos piores no gênero. Certa revista de "comics" - verdadeira cartilha de delinquência juvenil se gaba de ter 6 milhões de leitores.

Os bons "comics" de aventuras inocentes, esportes, de histórias de animais, de Walt Disney e asemelhadas, não somam, no momento, um quinto do total.

O perigo de tal literatura não se limita aos Estados Unidos. Exportada, traduzida e imitada por países de outras línguas, dissemina seus malefícios - e o Brasil é um dos que mais disso se ressentem.

Assinale-se, por igual, que todos os países sob a influência norte-americana foram invadidos por essa literatura, que suplantou a boa literatura em milhões de lares, criando sérios problemas aos pais na educação dos filhos.

Assinalando que se trata do "maior sucesso de publicação na História e a maior influência maciça sâbre a infância" - afirma um escritor norte-americano que, não obstante o "slogan" de que "o crime não compensa", o crime dessas publicações compensa bem: a seus... editôres.

No decurso de uma sessão da "The Association for the Advancement of Psychoterapy", realizada em New York, alguns especialistas foram chamados a se manifestar sôbre medidas a tomar relativamente à psicopatologia dos "comics". O psiquiatra Gershon Legnon - autor de um "Tratado Histórico dos "Comics" - revelou impressionante estatística, seguando a qual são sobremodo acentuados os malefícios acarretados por êsse tipo de literatura sôbre o psiquismo infantil, tra. zendo numerosos exemplares de crimes inspirados pela mesma; informou aos seus colegas que, em média, as crianças das cidades americanas lêm de 10 a 12 dessas revistas, por mês; admitindo que só haja uma cena de violência em cada página - e, habitualmente, há mais - teríamos, para cada criança, 300 cenas de agressões, ferimentos, tiros, estrangulamentos, etc., cada mês. Uma criança de seis anos de idade veria, por consequência, num período de 10 anos, "apenas" 36.000 cenas iguais!

Fácil compreender que a influência nociva dessa literatura é freqüentemente assinalada na origem de neuroses, psicopatias e psicoses.

Igualmente sério é o papel dessa literatura na etiologia da delinqüência infantil e juvenil. Entre muitos que se devotaram ao estudo dêste grave problema médico-social, opina Frederich Wertham, psiquiatra e diretor da Clínica Lafarge, em New York: "Anos de obser- 
vação de crianças desajustadas trouxeram-me a convicção de que o estímulo nocivo dos "comics" muito contribuiu para a delinqüência".

Também o suicídio tem sido observado em menores, sugestionados pelos "comics". Há muitas observações a respeito. Um dêsses casos: um menino que se enforcou; a seus pés, estava uma revista de "comics", aberta na página em que havia a gravura de um homem que havia sido enforcado.

Há, nessa literatura, heróis, habitualmente americanos, louros, belos, fortes, atléticos, invencíveis em relação a adversários - sempre negros, mestiços, eslavos ou orientais - cuịa feiura e falta de inteligência são exageradas ao máximo; há supermen que conhecem o segrêdo de se tornar invisíveis, de voar, de se transformarem em fogo, de manejar "raios da morte", de enfrentar qualquer perigo usando palavras mágicas; há mulheres muito sexy, sobremodo sedutoras, semi-nuas, a mostrarem "qualidades" não pròpriamente espirituais; há, ainda, nas revistas "de terror", cadáveres "vivos", monstros horripilantes criados por cientistas loucos. Há também "gangsters", perversos ao extremo, que torturam suas vítimas com refinamentos de crueldade - e tudo é mostrado por gravuras extraordinàriamente sugestivas. Numa dessas revistas, o personagem principal, um pervertido sexual, persegue suas vítimas - em número de 12 - que mata e disseca; outro, "diverte-se" esbofeteando moças, cortando-as com uma faca, furando-lhes os olhos.

Não podemos descrever tudo. Poderíamos levar horas, na enumeração das "lições" nocivas dessa perniciosa literatura, em conseqüência das quais passa a criança a viver num mundo mórbido de fantasia; no qual o intelecto é sempre superado pela fôrça bruta; em que enganar a Polícia e a Justiça são consideradas provas de inteligência; na qual a excitação sexual é a regra; na qual à falta corresponde sempre o castigo e o perdão não existe.

Compreende-se bem a razão de se formarem indivíduos com uma falsa noção da realidade e dos bons meios para as honestas vitórias na vida; com forte tendência para o devaneio mórbido; vendo, no sexo masculino, sòmente a fôrça física, e, na mulher, apenas o lado sensual.

Ninguém poderá, honestamente, duvidar do papel dessa literatura como poderoso agente de psico-desagregação e perversão infanto-juvenil, bem como fator criminogenético de relêvo, induzindo ao crime menores, predispostos ou não.

Através de louvável propaganda, levada a efeito pela imprensa esclarecida, no Brasil e nos Estados Unidos, ficou plenamente demonstrado o papel indiscutível dos "comics" na gênese da delinqüência de menores. Citaram-se numerosos exemplos de menores que culminaram no furto, em hold-ups, no homicídio até, em função das "lições" dessa literatura, cujos heróis se esforçavam em, fielmente, 
imitar. Em Curitiba, Capital do Estado do Paraná e outras cidades brasileiras, conhecemos casos iguais, em que os "comics" - cuja venda é lamentàvelmente livre, que se vêem por tôda a parte, nas mãos das crianças em especial - foram a indiscutível mola propulsora que induziu menores ao crime.

Deve-se assinalar a grande fôrça sugestiva dos "comics", atuando sôbre o espírito débil das crianças, uma de cujas características é, precisamente, a sugestibilidade fácil - razão por que sofrem, de maneira mais acentuada, a perniciosa influência dessa literatura peçonhenta (autêntico "veneno mental"), o que é sobremodo conhecido dos que se devotam ao estudo da psicologia social e criminal, e que constatam, na mesma, uma grande fonte de incitamento ao crime.

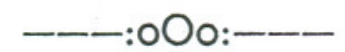

A moderna Psiquiatria não mais se pode limitar aos tratamentos especializados nos hospitais, nem à prática dos psiquiatras em seus consultórios. Evoluiu num sentido novo, de Psiquiatria Política, Psiquiatria Social. Se, como ramo da Medicina, cuida dos doentes, procurando curá-los, como Medicina ainda, mostra males sociais, traça regras, aponta caminhos, orienta, ensina, procurando prevenir os mesmos males.

Acabamos de assinalar o papel dos "comics" como poderosos fatôres psico-desagregadores, na infância e na adolescência. Frise-se que não combatemos todos os "comics", que os há inofensivos, que só procuram divertir. Reconhecemos até que apresentar uma historieta, através de gravuras, é maneira sobremodo interessante de despertar a atenção da criança; o que combatemos são os que disseminam uma literatura altamente maléfica, que lhe envenena a alma.

Lamentamos reconhecer que, até agora, nada resultou das medidas, tomadas por nosso govêrno, para proibir a venda livre dêste tipo de literatura, no Brasil.

Seria de desejar, portanto, que dêste Congresso, que reúne grandes nomes da Psiquiatria mundial, partissem proposições tendentes a alertar a atenção dos intelectuais norte-americanos contra êsse aspecto negativo da cultura de sua grande nação - que somos os primeiros a admirar por suas realizações construtivas - dados os males que os "comics" acarretam à infância e à adolescência.

Finalizemos com a lição do poeta latino Ovídio, bem ajustável ao temá desta comunicação:

\section{"Principiis obsta: sero medicina parata \\ Cum mala per longas convaluere moras"}

- se nos permitem traduzir:

"No comêço é que se deve atalhar os grandes males; tardio virá o remédio, depois de o mal haver criado raízes". 


\section{RÓLE DE LA MAUVAISE LITTÉRATURE DES "COMICS"(*) NORD-AMÉRICAINS SUR LE \\ PSYCHISME DES ENFANTS ET DES ADOLESCENTS}

(Communication présentée au Vème Congrès International de Psychiatrie Infantile, realisé à Scheveningen (Pays -Bas), aout 1962, par le

Prof. Dr. méd. Napoleão L. Teixeira

Professeur de Médicine Légale (Faculté de Droit) et de Clinique Psychiatrique (Faculté de Médecine), à I'Universiłé du Paraná (BRESIL)

Parmi les facteurs qui, au Brésil, jouent un rôle important dans la distorsion du psychisme des enfants et des adolescents, il faut souligner - à côté du mauvais cinéma, du mauvais théatre, de la mauvaise radio, de la mauvaise telévision, des mauvais livres, du jornalisme sensationaliste, etc. - l'influence fort nuisible de la mauvaise littérature infantile, apportée par les "comics" nord-américains, que de tout-puissants "Syndicates" journalistiques nous imposent, em poisonnant l'esprit des enfants et des adolescents de notre pays.

Fort disseminée au Brésil, reproduite et imitée par de nombreuses révues et nombre des plus grands journaux brésiliens, cette littérature-là - rares exceptions à part - n'a rien de bon, étant, au contraire, mauvaise, délétère et même dangereuse.

Nous avons, en synthèse, d'un côte, l'enfant, instable, impulsif, égoïste, imaginatif, suggestible - être d'imitation et non de raisonnement - et d'autre côte, nous avons les "comics" agissants de façon fort pernicieuse, perséverante, tenace, sur ce psychisme-là, à travers le plus vulnérable des organes des sens: la vue.

Dans l'année de 1948, seulement aux Etats Unis, ces publications étaient faites à la raison de 60 millions chaque mois, c'est-à-dire 720 millions annuels; en d'autres mots, plus que la circulation totale de dix des plus grands jornaux réunis. Aujourd'hui, le chiffre de 100 millions est déjà outrepassé.

Le "Chicago Tribune" rapporte que, dans ce pays-là, 25 à 30 millions de personnes lisent le "comic" "Dick Tracy", un des plus mauvais dans le genre. Une revue de "comics" - vraie abécedaire de lá délinquance juvénile - se vante d'avoir 6 millions de lecteurs.

Les bons "comics" d'aventures innocentes, de sports, histoires d'animaux, de Walt Disney ou pareils, ne comptent pas, en ce moment, qu'un cinquème du total.

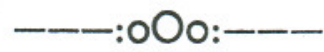

$\left({ }^{*}\right)$ "Comics" (Etats Unis), "bandes dessinées" (France), "histórias-em-quadrinhos" (Brésil); "fumetti" (Italie), etc. 
Le danger de cette littérature-là ne se borne pas aux Etats Unis. Exportée, traduite et imitée par les pays d'autres langues, dissémine ses maléfices - et le Brésil est de ceux qui s'en ressent le plus.

II faut signaler que tous les pays sous l'influence nord américaine ont été envahis par cette littérature-là, qui a supplantée la bonne littérature em million de foyers, en créant des problèmes sérieux aux parents dans l'education de leurs enfants.

En remarquant qu'il s'agit du "plus grand succès de publication dans I'Histoire, et la plus grande influence massive vis-à-vis de l'enfance" - affirme un écrivain nord-américain que malgré le "slogan" que "le crime ne compense pas", le crime de ces publications compense bien: à ses... editeurs.

Au cours d'une session de "The Association for the Advancement of Psychotherapy", realisée à New York, quelques spécialistes ont été inquirés dans le sens de se manifester à propos des mesures à prendre vis-àvis de la psychopathologie des "comics". Le psychiatre Gershon Legnon - auteur d'un "Traité Historique des "Comics" montra impressionante statistique, selon laquelle sont fort accentués les malefices apportés par ce type de littérature sur le psychisme infantile, en rapportant de nombreux exemples de crimes inspirés par cette littérature-là; informa ses collègues qu'en moyenne les enfants des villes américaines lisent, chaque mois, de 10 à 12 de ces révueslà; en admettant qu'il ait une seule scène de violence dans chaque page - et habituellement il y en a plus - nous aurions, pour chaque enfant, 300 scènes d'aggresisons, coups, coups-de-feux, strangulations, etc, chaque mois. Un enfant, agé de six ans, aurait vu alors, dans un délai de dix ans, "rien de plus" que 36.000 scènes semblabes!

II esta facile de comprendre que l'influence maladive de cette littérature est fréquemment à l'origine de futures névroses, psychopathies et psychoses.

Tellement sérieux est le rôle de cette littérature dans l'etiologie de la délinquance infantile et juvénile. Parmi beaucoup de savants qu se sont devoués à l'étude de ce grave problème médico-social, opine Frederich Wertham, psychiatre et directeur de la Clinique Lafarge, à New York; "Des années d'observation d'enfants "desajustés" m'ont apporté la conviction que la simulation nuisible des "comics" a beaucoup contribué pour la délinquance".

Le suicide aussi a été observé chez les mineurs, suggestionés par les "comics". II y a un bon nombre d'observations; un de ces cas, un garçon s'est pendu: à ses pieds, il y avait une révue de "comics", ouverte dans la page où il y avait la gravure d'un homme qui avait subi le supplice de la pendaison.

II y a, dans cette littérature-là, des héros, presque toujours ianques, blonds, beaux, athlétiques, invéncibles vis-à-vis de ses ad- 
versaires - toujours noirs, métis, slaves ou orientaux - dont la laideur et le manque d'intelligence sont fort exagérées; il y e a des supermen, qui connaissent le secret de se fairent invisibles, de s'envoler, de se transformer en feu, de manoeuvrer "foudres de la mort", de faire face à quelque danger en employant des mots magiques; il y a des femmes fort sexy, très séduisantes, a demi-nues, montrant des "qualités" non proprement... spirituelles; il y a, dans les revues "de terreur", des cadavres "vivants", des monstres horripilants crées par de savants fous. Et il y a aussi des "gangsters", pervers au maximum, qui torturent ses victimes avec raffinements de cruauté - et tout est montré par des gravures fort suggestives. Dans une de ces revues, le personnage principal, un perverti sexuel, poursuit ses victimes - en nombre de 12 - qui tue et dissèque; un autre se "divertit" em souffletant des jeunes-filles, en les coupant avec un couteau et, finalement, en leur trouant les yeux.

Nous ne pouvons pas tout décrire. Nous pourrions passer des heures dans l'énumération des "leçons" maladives de cette pernicieuse littérature, en conséquence de laquelle passe l'enfant a vivre dans uns monde morbide de fantaisie, où l'intellect est toujours surpassé par la force brute; où tromper la Police et la Justice sont considerés démonstrations d'intelligence; où l'excitation sexuelle est la règle; où à la faute correspond toujours le châtiment et le pardon n'existe pas.

On comprend bien la raison que se forment des individus avecune fausse notion de la réalité et des bons moyens pour les honnêtes victoires dans la vie; avec une forte tendance pour la rêverie morbide; ne voyant, dans le sexe masculin, rien que la force physique et, dans la femme, rien que l'aspect sensuel.

Personne ne pourra honnêtement douter du rôle de cette littérature comme un puissant agent de psycho-desaggrégation, de perversion infantile et juvénile, bien aussi comme facteur criminogenétique de relief, en induisant au crime des mineurs, prédisposés ou non.

A travers une louable propagande, réalisée aux Etats Unis et au Brésil par la presse éclaircie, a été pleinement démontré le rôle indiscutable des "comics" dans la génèse de la délinquance des mineurs. Ont été rapportés des nombreux exemples de mineurs qui culminerent dans le vol, hold-ups, dans l'homicide même, en fonction des "leçons" de cette littérature-là, dont ils s'efforçaient d'imiter fidèlement les héros. À Curitiba, capital de l'État du Paraná et autres villes brésiliennes, nous connaissons de nombreux cas pareils, où les "comics" - dont la vente est lamentablement libre et qu'on voit partout, dans les mains des enfants en particulier - ont été l'indiscutable ressort propulseur qu'a induit des mineurs au crime. 
Il faut rappeler la grande force suggestive de ces revues-là, en agissant sur l'esprit débile des enfants, dont une des caractéristiques est précisement la suggestibilité facile - raison par laquelle subisse, de façon plus accentuée, l'influence pernicieuse de cette littérature venimeuse (authentique "poison mental"), ce qui est bien connu de tous ceux qui se devouent à l'étude de la psychologie sociale et criminelle, et qui constatent dans cette littérature, une des grandes sources de l'incitement au crime.

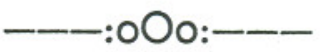

La moderne Psychiatrie ne peut plus se borner aux traitements spécialisés dans les hopitaux et à la pratique des psychiatres dans ses bureaux de consultations. Elle a evolué dans un nouveau sens, de Psychiatrie Politique et Psychiatrie Sociale. Si, comme branche de la Médecine, elle soigne les malades, en cherchant les guerir, comme Médecine encore elle montre les maux sociaux, elle trace des règles, elle pointe des routes, oriente, enseigne, cherchant à prévenir ces maux.

Nous venons de signaler le rôle des "comics" comme puissants élements psycho-desaggrégateurs dans l'enfance et dans l'adolescence. Il faut signaler que nous ne nous battons pas contre tous les "comics", qu'il y en a d'inoffensifs, qui ne cherchent qu'a amuser. Nous reconnaissons que présenter une histoirette a travers des gravures, c'est une façon fort interéssante d'éveiller l'attention de l'enfant; ce que nous combattons cont ceux qui disséminent une littérature fort maladive, qu'empoisonne son âme.

Nous nous lamentons de reconnaïtre que, jusqu'à maintenant, rien n'a resulté des mesures de notre gouvernement, pour interdire la libre vente de ce type de littérature.

Alors, ce serait à désirer que de ce Congrès, qui assemble de grands noms de la Psychiatrie mondiale, partissent des propositions tendant à alerter l'attention des intellectuels nord-américains contre cet aspect négatif de la culture de sa grande nation - que nous sommes les premiers à admirer pour ses realisations constructives - signalés les maux qu'occasionent les "comics" à l'enfance et à l'adolescence.

Nous finissons avec la leçon du poète latin Ovide, bien ajustable au sujet de cette communication:

"Principiis obsta: sero medicina parata

Cum mala per longas convaluere moras"

- si vous nous permettez de traduire:

"Dans le commencement, c'est là qu'il faut couper court aux grands maux; tard viendra le remède, après s'être enracinée la maladie". 


\title{
THE UNDESIRABLE INFLUENCE OF NORTH-AMERICAN "COMICS"(*) ON THE PSYCHE OF CHILDREN AND ADOLESCENTS
}

\author{
Paper to be presented at the 5TH INTERNATIONAL \\ CONGRESS OF CHILD PSYCHIATRY, to take place \\ in Scheveningen (Netherlands), in the month of Au- \\ gust, 1962, by Dr. Napoleão L. Teixeira, M.D., Pro- \\ fessor of Legal Medicine (School of Law), and \\ Professor of Psychiatry (School of Medicine), Uni- \\ versity of Paraná (Brasil).
}

Among the factors which in Brasil play an important part in the warping of the mental and emotional development of children and adolescents - along with bad movies, bad plays, bad radio programs, bad television, bad books, sensational journalism, etc. - North-American "comics" can also be cited as a vicious influence.

This literature, which powerful journalistic syndicates impose on their Brazilian readers, is poisoning the minds of children and adolescents in our country. Widely distributed in Brazil, reproduced and imitated in many major Brazilian magazines and newspapers, this literature - with a few rare exceptions - has nothing of value but, on the contrary, is evil and even dangerous.

In short, we have the child, on the one hand, by nature unstable, impulsive, egocentric, imaginative, suggestionable - a creature of imitation rather than reason - and on the other hand, we have the "comics", acting in a very pernicious maner, leaving an enduring impression on the psyche of the child, through the most vulnerable of the sensory organs - sight.

During 1948, in the United States alone, 60 million such "comics" were published each month, that is, 720 million annually; in other words, a circulation greater than that of the ten major American newspapers put together. At the present time, this circulation exceeds 100 million per month.

The "Chicago Tribune" reports that in the United States 25 to 30 million people read the "comic" strip "Dick Tracy", one of the worst of its genre. One magazine - a veritable primer for juvenile delinquency - boasts 6 million readers.

The good "comics" of innocent adventure, sports, animal stories, produced by. Walt Disney and similar creators, do not account for more that one fifth of the volume of the "comics" currently produced.

(*) "Comics" (United States); "histórias-em-quadrinhos" (Brazil); "bandes dessinées" (France);

"fumetti" (Italy), etc. 
The danger of this literature is not confined to the United States. Exported, translated and imitated by other countries, its evil effects are disseminated, and Brazil is one of the countries which feels its influence most strongly.

It can be pointed out that all the countries under North American influence have been almost uniformly invaded by this literature, which supplants good literature in million of homes, creating serious problems for parents in the education of children.

Pointing ou that we are dealing with the "greatest publication enterprise in History, and the major mass influence on children", a North American writer, states that in spite of the slogan "crime doesn't pay", the crime of these publications pays its editors very well.

During a meeting of "The Association for the Advancement of Psychotherapy", in New York, several specialists were called upon to suggest measures that should be taken relative to the psychopathology of "comics". The psychiatrist Gershon Legnon, author of an "Historic Treatise on Comics", revealed impressive statistics which strikingly illustrate the ill effects of this type of literature on the working of a child's mind, citing many examples of crimes inspired by the same influence. He informed his coleagues that, on the average, children in American cities regularly read from 10 to 12 of these magazines per month. Figuring that each page has at least one scene of violence, and usually more, each child would be exposed to 300 scenes of aggressions, stabbings, shootings, strangulations, etc., each month. A six year old child, therefore, would "merely" see 36 thousand such scenes in a period of 10 years.

That neuroses, psychoses, and other pathological conditions are frequently attributed to the poisonous influence of such literature, is readily understandable.

This literature plays an equally serious role in the etiology of child and juvenile delinquency. Among the many who have studied this grave social-medical problem, Dr. Frederich Wertham, psychiatrist and director of the Lafarge Clinic in New York, declares: "Years of observation of maladjusted children have led me to the conclusion that the noxious stimulus of comics have greatly contributed to delinquency in general".

Suicide has also been observed among minors, suggested by the "comics". Among many such cases, there is the one of a child who hanged himself, and had at his feet a "comic" open to a page in which there was an illustration of a man who had been hanged.

There are heroes in this literature, nearly always Americans, who are depicted as handsome, strong, athletic, invincible in relation to 
their adversaries, who are near always negroes, mulattoes, slavs, or orientals - whose ugliness and lack of intelligence are extremely exaggerated; there are supermen who have magical powers which enable them to render themselves invisible, to fly, to transform themselves into fire, to direct "death rays" and to confront every peril with magic words; there are sexy, seductive, half-nude women, who display highly unspiritual "qualities"; in the terror magazines there are living corpses, and other horror-inspiring monsters, created by mad scientists. There are also gangsters of extreme depravity, who torture their victims with refined cruelty - which is all shown through extraordinarily suggestive ilustrations. In one of these magazines, the principal character, a sexual pervert, pursues his victims, twelve in all, whom he kills and dissects. Another, "amuses" himself by slapping girls, cutting them with a knife and piercing their eyes.

We cannot describe everythning. We could spend hours enumerating the criminal "lessons" of this pernicous literature, which cau. ses children to live in a world of morbid fantasy, in which intelect is always subordinated to brute force; in which the ability to fool the police and justice is considered proof of intelligence; in which sexual excitement is the rule; in which every fault is punished and pardon does not exist.

It is certainly understandable that individuals are being formed with a false notion of reality and a false notion of how to succeed honestly in life; with a strong tendency toward morbid day-drea. ming, seeing in man only brute force and in woman only sexuality.

No one can honestly doubt the role of this literature as a powerful agent of psychologicbal disintegration and perversion of children and adolescents, as well as a factor which can induce minors to crime, whether or not they are so predisposed.

Through praiseworthy propaganda, carried out by an honest press in Brazil and in the United States, the indisputable influence of "comics" has been fully established as an origin of juvenile delinquency. Numerous examples can be cited of minors who commited thefts, hold-ups and even homicides, in accordance with the lessons of the "comics", whose heroes were faithfully imitated. In Curitiba, capital of the State of Paraná, and in other Brazilian towns, we know of many similar cases, in which the "comics" - whose sale is so lamentably uncontrolled, that they can be seen, everywhere, especially in the hands of children - are an unquestionable incentive for the crime of minors.

It is evident that the "comics" are a great suggestive force, acting on the defenseless spirit of children, one of whose characterics is precisely their easy suggestibility. For this reason they su- 
ffer to a great degree from the pernicious influence of this venomous literature (authentic "mental poison"). It is a fact well known among those who devote themselves to the study of social and criminal psychology, that this literature is one of the greatest inducements to crime.

\section{---::000:---}

Modern psychiatry can no longer be limited to specialized treatments in hospitals, nor to psychiatric practice in offices. It has evolved in a new direction, into Political or Social Psychiatry. If, like other branches of Medicine, it is concerned with the cure of illnesses within its speciality, then it must expose social ills, and direct the means of preventing these same ills.

We have just pointed out the role of the "comics"; as a powerful factor in psychic disintegration, both in childhood and adolescence We do not oppose all "comics", for there are inoffensive ones, which seek only to entertain. We realize that the presentation of a story by means of pictures can be a very stimulating way of arousing a child's interest. We oppose only those which disseminate a highly evil kind of literature, which poisons the mind of the child.

We regret that, to date, nothing has resulted from the measures taken by our government to prohibit the free sale of this type of literature in Brazil.

Therefore, it is to be hoped that this Congress, which brings together the greatest names in psychiatry from alls parts of the world that proposals will be made tending to alert North American intellectuals to this negative aspect of the culture of their great nation which we are the first to admire for its constructive accomplishments.

Let us conclude with a lesson from the Latin poet Ovid, very appropriate to the theme of this paper:

"Principiis obsta: sero medicina parata

Cum mala per longas convaluere moras"

which we take liberty of translating as follows:

"Great maladies should be stopped in the beginning; remedies will be too late, if the evil has already taken root". 